\title{
Химия
}

DOI: $10.18083 /$ LCAppl.2021.4.85

\section{DEVELOPMENT OF LIQUID CRYSTALLINE AND ANISOTROPIC MATERIALS CHEMISTRY IN BELARUS}

\author{
Vladimir S. Bezborodov *
}

\author{
Belarusian State Technological University, Minsk, Belarus \\ *Corresponding author: v_bezborodov@yahoo.com, https://orcid.org/0000-0003-1903-7957
}

\begin{abstract}
Advances of liquid crystalline and anisotropic materials chemistry in Belarus are discussed and considered using examples of synthetic approaches developed in recent decades. It was shown that anisotropic and liquid crystalline compounds can be obtained using targeted transformations of the corresponding 3,6disubstituted cyclohex-2-enones, trans-2,5-disubstituted cyclohexanones, 5-substituted cyclohexane-1,3-diones, 3,5-disubstituted 2-isoxazolines, 1,2-disubstituted cyclopropanols and unsaturated epoxyketones.

Key words: synthesis, liquid crystals, anisotropic compounds

For citation: Bezborodov V. S. Development of liquid crystalline and anisotropic materials chemistry in Belarus. Liq. Cryst. and their Appl., 2021, 21 (4), 85-88. DOI: 10.18083/LCAppl.2021.4.85.
\end{abstract}

Краткое сообщение

УДК 544.25:542.9

\section{РАЗВИТИЕ ХИМИИ ЖИДКОКРИСТАЛЛИЧЕСКИХ И АНИЗОТРОПНЫХ МАТЕРИАЛОВ В БЕЛАРУСИ}

\section{Владимир Степанович Безбородов*}

Белорусский государственный технологический университет, Минск, Беларусь *Автор для переписки: v_bezborodov@yahoo.com, https://orcid.org/0000-0003-1903-7957

Аннотация. Достижения химии жидкокристаллических и анизотропных материалов в Беларуси обсуждены и рассмотрены на примерах подходов к синтезу, разработанных в последние десятилетия. Показано, что анизотропные и жидкокристаллические соединения могут быть получены с использованием иеленаправленных превращений, соответствующих 3,6-дизамещенных ичилогекс-2-енонов, транс-2,5дизамещенных ичклогексанонов, 5-замещенных ииклогексан-1,3-дионов, 3,5-дизамещенных 2изоксазолинов, 1,2-дизамещенных ииклопропанолов и непредельных эпоксикетонов.

Ключевые слова: синтез, жидкие кристаллы, анизотропные соединения

Для цитирования: Bezborodov V.S. Development of liquid crystalline and anisotropic materials chemistry in Belarus. Liq. Cryst. and their Appl., 2021, 21 (4), 85-88. DOI: 10.18083/LCApp1.2021.4.85.

(C) Bezborodov V. S., 2021 
Until the 60 s of the last century, the works on synthesis and study of mesomorphic properties depending on chemical structure of liquid crystals (LC) possessed largely academic character. Since the 1960s, after J. Fergason (USA) registered patents on the use of cholesteric liquid crystals (ChLCs) for visualization of thermal and microwave fields and in other applications, the interest in LCs has sharply increased.

In many countries (USA, Japan, West Germany, East Germany, UK, etc.), as well as in the USSR, the works on the synthesis and investigations of ChLCs began to be intensively carried out. Subsequent discoveries of electro-optical effects in nematic and smectic liquid crystals, caused by reorientation of molecules under the influence of electric field, stimulated the increase in the number of works and patents on the synthesis, physical properties study and application of LC. As the result, by the 80 s, a new specific branch of organic chemistry named "Liquid Crystals Chemistry" has been formed. It has its own synthetic strategy to obtain mesomorphic compounds and various dopants needed for the creation of effective LC materials. It deals with a thorough analysis of the relationship between the structure of mesomorphic compounds and their properties, knowing of which is essential for the targeted search of liquid crystals with improved operating parameters.

By this time, a scientific school of Liquid Crystal materials Chemistry was formed in Belarus, the center of which was based at the Research Institute of Applied Physical Problems of the Belarusian State University. Later, the scientists from the Department of Organic Chemistry of the Belarusian State Technological University joined to these studies.

At present time, despite the advances achieved in the synthesis of liquid crystal compounds and the creation of various compositions on their base, the development of liquid crystal compounds with optimal physicochemical parameters is still undoubtedly relevant. Methods for the synthesis of these compounds should be characterized by the availability of starting reagents, the absence of complex technological stages, and must have high yield of final products in combination with their chemical purity.

Having more than 45 years of experience in the investigations of various types of liquid crystal materials, Belarusian scientists have developed original approaches to the synthesis and creation of LC compounds for the use in all types of electro-optical display devices, but also new anisotropic materials with a wide range of practical applications [1]. The pro- posed schemes for obtaining of new materials and anisotropic substances, modeling various processes are based on the regularities of the evolutionary development of natural organic compounds; numerous data obtained in recent decades in the study of liquid crystals and ordered media. It should be added, that the use of the anisotropy is very promising for the design of new molecular structures (molecular engineering), films, liquid crystals, membranes, micelles, anisotropic ensembles of molecules and biological systems.

Thus, as a result of the research carried out, the new methods for the synthesis have been developed and the following liquid crystals have been obtained:

- polyphenylenes with high optical anisotropy value $(\Delta n)$;

- hydrogenated analogues of 4-alkylbenzoic acids, derivatives of phenylcyclohexene, phenylcyclohexane, cyclohexyldiphenyl and $\beta$-arylethylcyclohexane with low values of $\Delta n$, dynamic $(\eta)$ or kinematic ( $v)$ viscosity and a wide temperature range of nematic phase;

- highly polar mesomorphic materials.

The distinctive advantages of these methods are the availability of starting reagents, the unambiguous route of reactions in the absence of complex technological stages, and a high yield of the target products.

For the synthesis of mesomorphic carbocyclic compounds, the original approaches have been proposed. In two or three stages, they make it possible to obtain compounds differing in the combination of benzene, cyclohexane or cyclohexene rings, bridging fragments, and the number and position of lateral substituents in the cyclic fragments. For the preparation of liquid crystals with higher values of positive $(+\Delta \varepsilon)$ or negative $(-\Delta \varepsilon)$ dielectric anisotropy compared to known mesogens, the original synthesis methods of 1,3,2-dioxaborinane derivatives and polyfluorophenylenes using new combinations of structural fragments have been designed [2]. The general formulas of the obtained LC compounds (A, B) are shown in Fig. 1.

For the synthesis of carbocyclic and heterocyclic nematic mesogens, "shock-free" ferroelectric liquid crystals, improved anisotropic monomers, surfactants with pronounced rod-like molecular and the high orientational order, it was proposed $[3,4]$ to use polyfunctional anisotropic intermediates, such as 3,6-disubstituted cyclohex2-enones (I), trans-2,5-disubstituted cyclohexanones (II), 5-substituted cyclohexane-1,3-diones (III), 3, 5-disubstituted 2-isoxazolines (IV, V), 1,2-disubstituted cyclopropanols (VI), and unsaturated epoxy ketones (VII). 


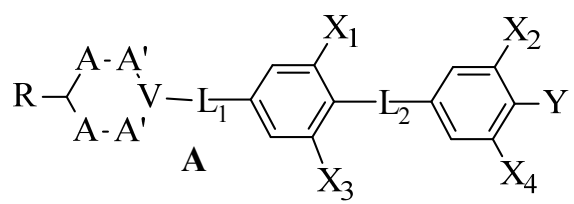

Fig. 1. Structural formulas of LC compounds, where: A, A' - O, C; V-C, B, N; $\mathrm{X}_{1-4}-\mathrm{H}, \mathrm{F}, \mathrm{Cl}, \mathrm{CF}_{3}, \mathrm{CH}_{3}$; $\mathrm{Y}-\mathrm{F}, \mathrm{Cl}, \mathrm{CN}, \mathrm{NCS}, \mathrm{CF}_{3}, \mathrm{OCF}_{3} ; \mathrm{K}$ - cyclohexene, cyclohexane, benzene ring; $\mathrm{R}, \mathrm{R}$ ' - alkyl, alkoxy radical; $\mathrm{L}_{1-2}$ - bond or $\mathrm{CH}_{2} \mathrm{CH}_{2}$, $\mathrm{COO}$

It was found [3] that the targeted synthesis of polyfunctional anisotropic intermediates (I-VII) (Fig. 2) and their following transformations open the way for obtaining new anisotropic and liquid crystalline materials promising for practical use in various fields of science and technology. This approach required adap- tation and optimization of known synthesis methods (condensation of $\beta$-dicarbonyl compounds, the Kulinkovich, Mitsunobu, Suzuki reactions, etc.) to achieve acceptable yields, increase the fundamental and applied efficiencies of the use of these anisotropic intermediates and their modification products.

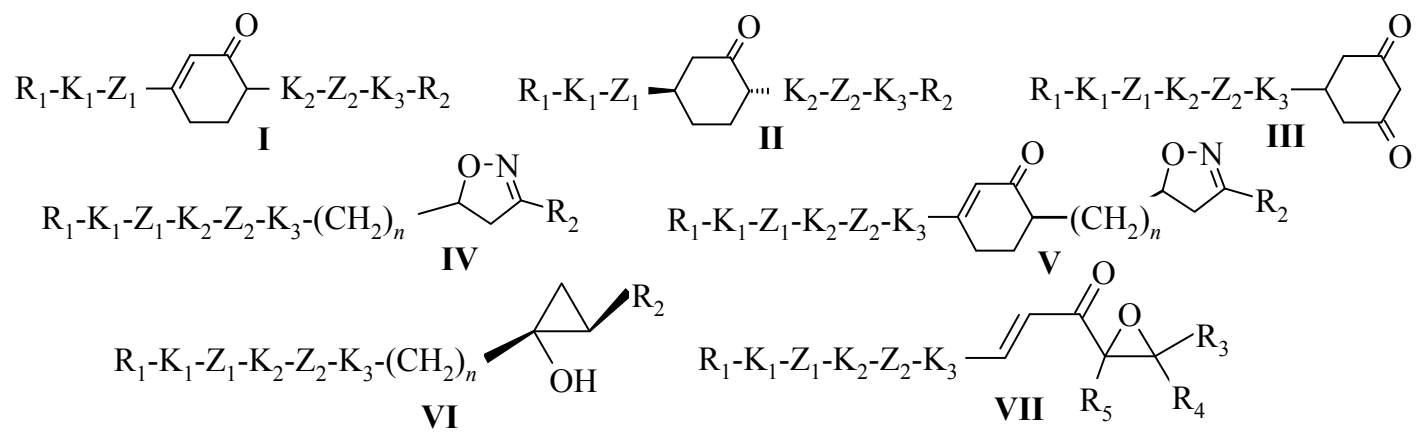

Fig. 2. Polyfunctional anisotropic compounds: $\mathrm{R}_{1,2}$ - alkyl, alkoxy radical, $\mathrm{F}, \mathrm{Cl}, \mathrm{CN}, \mathrm{CF}_{3}, \mathrm{OCF}_{3}$, chiral fragment; $\mathrm{K}_{1-3}-$ bond or cyclohexene, cyclohexane, benzene ring; $n=0-5 ; \mathrm{Z}_{1,2}-$ bond or $\mathrm{CH}_{2} \mathrm{CH}_{2}$, other bridge fragment; $1=0,1 ; \mathrm{R}_{3-6}-\mathrm{H}$, alkyl, aryl fragment

Concerning our studies in the field of macromolecular compounds, it was showed that the anisotropic properties and self-organization ability of natural polymer molecules, for example, cellulose and chitin, make it possible to obtain original highly ordered composites with a wide practical applications range by incorporating biopolymers into a synthetic polymer matrix. The use of peptide and carbohydrate building blocks in the structure of polymer allows not only to improve mesomorphic behavior and properties, but also control the structure ordering and biological functionality.

Undoubtedly, the proposed methodology of the development of anisotropic substances and materials is creative, it has a number of distinctive advantages, in comparison with the known methods of obtaining sim- ilar structures, and modeling biological systems. It can be successfully used for the design of new generations of anisotropic materials that are not inferior in properties to natural.

It is obvious that the study of anisotropic compounds, natural materials, their self-organization processes in physicochemical systems, and the use of bioevolution models are the basis for the development of modern materials science. In this regard, it becomes essential to move from the chemistry of individual molecules to the supramolecular chemistry of anisotropic compounds, namely, to a new research direction - anisotropic materials science that deals with the detailed study of self-organization processes underlying the creation of natural materials and origin life on Earth. 


\section{References}

1. Bezborodov V. S. Liquid Crystals Chemistry. Minsk : BSTU, 2017. 277 p. (in Russ.).

2. Bezborodov V.S., Lapanik V.I., Mikhalyonok S.G. Liquid crystalline compounds with positive dielectric anisotropy. Liq. Cryst. and their Appl., 2015, 15 (2), 618 (in Russ.).

3. Bezborodov V.S., Mikhalyonok S.G., Kuz'menok N.M., Lapanik V.I., Sasnouski G.M. Intermediates for the preparation of liquidcrystalline and anisotropic ma- terials. Liq. Cryst. and their Appl., 2014, 14 (4), 59-73. (in Russ.).

4. Bezborodov V.S. Anisotropic substituted cyclohex-2enones - synthesis, transformations and prospects of practical application. Liq. Cryst. and their Appl., 2021, 21 (1), 5-22 (in Russ.).

DOI: $10.18083 /$ LCAppl.2021.1.5.

Поступила 22.09.2021, одобрена 18.10.2021, принята 22.10.2021 Received 22.09.2021, approved 18.10.2021, accepted 22.10.2021 